\title{
From the drawing board to the field: an example for establishing an MPA in Penghu, Taiwan
}

\author{
HERNYI J. HSIEH ${ }^{\mathrm{a}, \mathrm{d}}$, CHAOLUN A. CHEN $^{\mathrm{b}}$, CHANG-FENG DAI $^{\mathrm{d}, *}$, WUHSIUNG OU ${ }^{\mathrm{c}}$, \\ WAN-SEN TSAI ${ }^{\mathrm{a}}$ and WEI-CHENG SU ${ }^{\mathrm{a}}$ \\ a Penghu Marine Biology Research Center, Fisheries Research Institute, Council of Agriculture, Penghu 880, Taiwan \\ ${ }^{\mathrm{b}}$ Research Center for Biodiversity, Academia Sinica, Nankang, Taipei 115, Taiwan \\ ${ }^{\mathrm{c}}$ Department of Environmental Biology and Fisheries Science, National Taiwan Ocean University, Keelung 202, Taiwan \\ ${ }^{\mathrm{d}}$ Institute of Oceanography, National Taiwan University, Taipei 106, Taiwan
}

\begin{abstract}
1. In order to promote the establishment of the first marine protected area (MPA) in Taiwan, the conservation values of 12 reef sites in the Penghu Islands were evaluated. The results together with a 6-year surveillance programme revealed that the Chinwan Inner Bay (CIB) possesses the best coral community in the Penghu Islands with the highest coral cover, high species diversity and habitat types, as well as a high conservation value.

2. Utilization of biological resources and socio-economic factors of CIB were investigated by intensive field surveys and a complete visit-and-poll survey respectively. Most of the fishing at CIB is for recreational purposes and is characterized by low investment, low harvest rates, high dependence on weather conditions, and self-consumption.

3. The socio-economic data showed that there was basically no direct conflict of interests with local communities at two neighbouring villages, and most local residents indicated that they would support the MPA proposal.

4. A blueprint for a CIB MPA based on the results of these biological and socio-economic investigations is proposed. Environmental threats including anchor damage and the predation of Drupella snails need to be ameliorated and monitored through the implementation of appropriate management. The involvement of local communities is key to the success of this MPA and environmental education is recommended to promote public awareness.
\end{abstract}

Copyright (C) 2007 John Wiley \& Sons, Ltd.

Received 10 February 2006; Revised 11 October 2006; Accepted 27 November 2006

KEY WORDS: marine protected area; coral community; artisanal fishery; socio-economic value; conservation value

*Correspondence to: Chang-feng Dai, Institute of Oceanography, National Taiwan University, 106, Taipei, Taiwan. E-mail: corallab@ntu.edu.tw 


\section{INTRODUCTION}

Over the past 20 years, attention has been given to the need for conservation of marine ecosystems, and the establishment of marine protected areas (MPAs) has been widely recommended as an effective mechanism for protecting marine biological resources (Sumaila, 1998; Stevens, 2002). There is a growing consensus that MPAs can act as an integral component of any marine management plan (Lauck et al., 1998; Alder et al., 2002), and designating a certain portion of the total marine area as MPAs has been suggested in order to maintain sustainable fish stocks (Costanza et al., 1998). Decision makers, managers and scientists are eager to establish quantitative or empirical bases as to the minimum size of MPAs necessary to achieve this goal. A minimum of $20-30 \%$ of coral reef habitat as no-take reserve was proposed, based on the precautionary principle as well as empirical and modelling studies of reserves (Bohnsack et al., 2000). Although the rationale of $20-30 \%$ was criticized for its narrow extrapolation from very specific localized studies of particular fisheries within particular habitats (Agardy et al., 2003), this criterion was adopted by various advocates of MPAs and fishery managers as a dogmatic standard for no-take reserves (e.g. USCRTF, 2000). A comprehensive marine conservation strategy should involve protection of both representative and distinctive habitats in a network of MPAs (Ballantine, 1997). By protecting marine ecosystems and their populations, no-take reserve networks can reduce risk by providing important insurance for fishery managers against over-exploitation of individual populations (Murray et al., 1999). Such a strategy would require a novel synthesis of relationships between 'species' and 'spaces' approaches to marine conservation by asking how it is possible to take the best advantage of both approaches, rather than seeing them as being in conflict (Roff and Evans, 2002).

In selecting candidate MPAs, the objectives should be to maximize protection of biodiversity, while minimizing economic, cultural and social costs (Roff and Evans, 2002). Thus both ecological and socioeconomic issues have to be considered throughout the processes involved in identifying, selecting, and establishing MPAs (Beck and Odaya, 2001; NRC, 2001; Kaiser, 2004). MPAs have the potential to increase and protect fish stocks for spawning, and to export larvae, recruits and exploitable adults to adjacent fishing grounds (McClanahan and Mangi, 2000). Restrictions on traditional access rights to exploit resources can cause misunderstandings and difficulties in promoting spatial protection measures. It is therefore fundamental to respect local fisheries and other extractive activities when designing MPAs (Evans and Birchenough, 2001) as well as other social and cultural considerations. In addition, early continued involvement of and mutual communications with the local communities and stakeholders is crucial for the effectiveness of MPAs. The aims of the MPAs are also key to success and broad acceptance. Employing multiple use MPAs including no-take areas as important tools may help achieve consensus towards the long-term sustainable use and conservation of marine systems (Agardy et al., 2003). If appropriately sited and designed, MPAs may not only protect biodiversity, but may also act as natural fish hatcheries and nurseries leading to the export of juveniles of many species to other areas (Evans and Birchenough, 2001).

There are currently 25 fishery resource conservation areas in Taiwan; however, strictly speaking, none of them can be regarded as an effective MPA (Dai, 1997). The failure of these fishery resource conservation areas is mainly due to lack of support from local fishers and resource users. The lack of convincing data to show the positive effects of setting up fishery resources conservation areas is a major difficulty of promoting MPAs. Owing to the severe degradation of coral reefs and coastal fishery resources (Dai, 1997; Jeng et al., 1999), there is an urgent need to conserve marine resources and a consensus has been reached to establish more effective MPAs (Dai et al., 2002; Kimura et al., 2004).

In 2000, the county government and NGOs in Penghu, Taiwan, planned to set up a model to demonstrate the positive effects of resource management and conservation. Traditionally, fishing has been a major source of revenue in the Penghu Islands, and local people used to declare ownership of the sea or land around their village or island. Thus, there was the potential for serious protests and violent confrontations to occur if no-fishing areas in Penghu were promoted without local support. A less 
controversial candidate site for an MPA was urgently needed to demonstrate the advantages and spillover profits that an MPA can bring to local people (Rowley, 1994). In this study, the conservation values (Edinger and Risk, 2000) of 12 reef sites in Penghu Islands were examined and, by considering the results of a long-term reef monitoring programme, the Chinwan Inner Bay (CIB) was selected as the target site for an MPA. Detailed socio-economic and environmental studies to promote the establishment of this MPA were then conducted with the aims of biodiversity conservation in the core zone, and fishery management and public demonstration/ education in the buffer zone as well.

\section{MATERIALS AND METHODS}

\section{Location}

The Penghu Islands (the Pescadores) are located in the middle of the Taiwan Strait and extend for a distance of less than $70 \mathrm{~km}$ from north to south $\left(119^{\circ} 20^{\prime}-119^{\circ} 50^{\prime} \mathrm{E} ; 23^{\circ} 10^{\prime}-23^{\circ} 50^{\prime} \mathrm{N}\right)$. The marine environment is mainly influenced by water masses from the South China Sea, a branch of the Kuroshio Current, and coastal waters of China (Figure 1). Owing to the effects of underwater geographic barriers (the Formosa Bank in the southern part of the Taiwan Strait and the Chung-Yun Rise in its middle), water circulation in the Strait exhibits obvious seasonal variations (Jan et al., 2002). These currents are also responsible for the dispersal and transportation of larvae and juveniles of various marine organisms

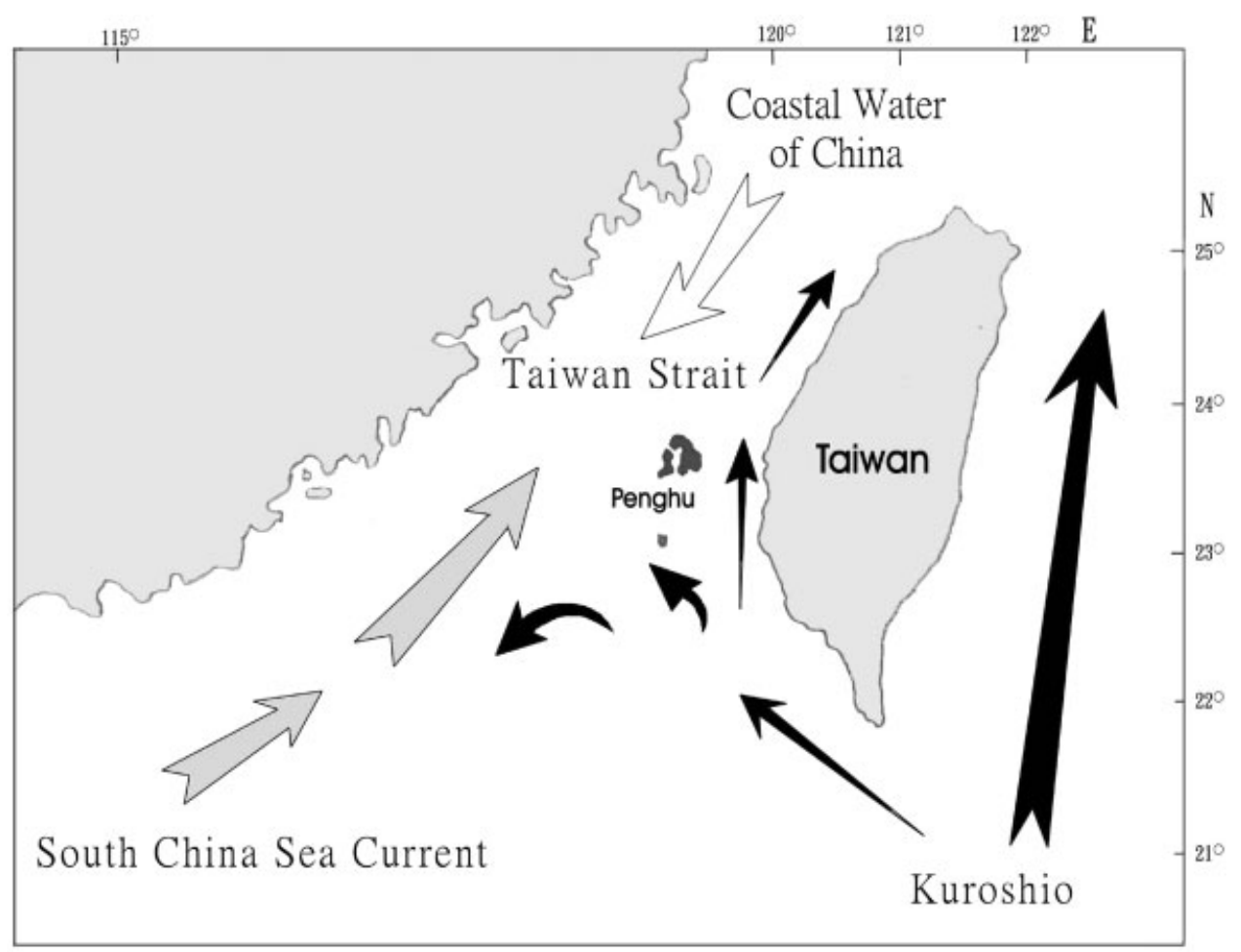

Figure 1. Location of Penghu Islands and the major current systems. 
(Chen, 1999). The dominant geology of the Penghu Islands is basalt rocks, which was deposited approximately 10-20 million years ago (Juang and Chen, 1992). CIB is located in an ancient crater to the south of the inner sea of the Penghu Islands (Figure 2).

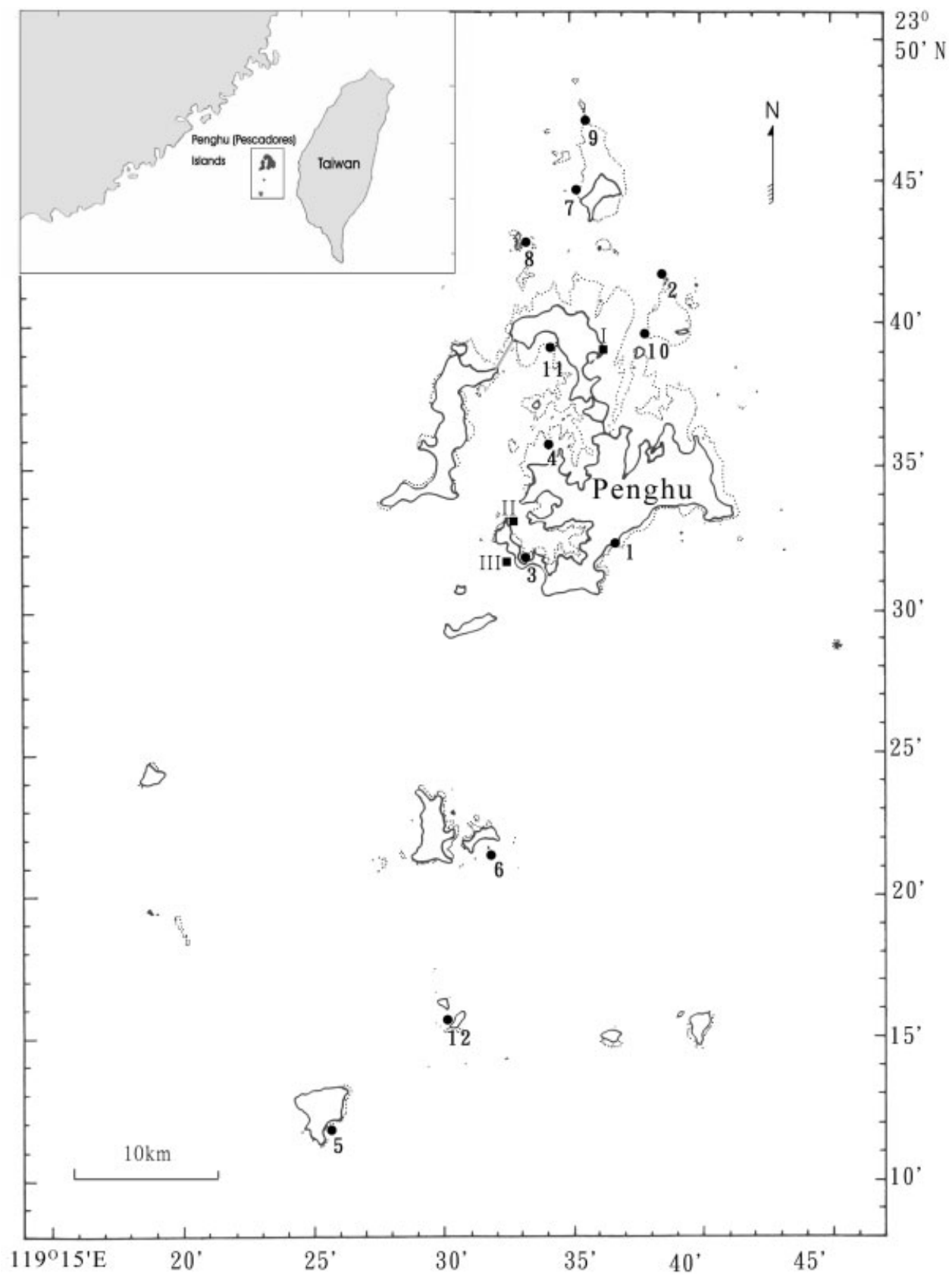

Figure 2. Location of the Penghu Islands (Pescadores) and the 12 survey sites (labelled as ' 1 ', 1: AI, Aimen; 2: CD, Chudra; 3: CIB, Chinwan Inner Bay; 4: CK, Chungkwang; 5: CM, Chimei; 6: DW, Dawen; 7: GP, Gipei; 8: GU, Gupo; 9: MD, Mudo; 10: PP, Ponpon; 11: WT, Watung; 12: YP, Yupin) and the other three sites for Reef Check monitoring (labelled as ' $\mathbf{\square}$ ', I: Chitou; II: Shertosan; III: Chinwan Outer Bay). 


\section{Conservation values}

The conservation value, an easy-to-determine and non-taxonomically based idea (Edinger and Risk, 2000), was applied to evaluate and compare the reef conditions at 12 sites which were surveyed in the Penghu Islands (Aimen, Gipei, Mudo, Ponpon, Dawen, Chimei, Chudra, Yupin, Chungkwang, Gupo, CIB and Watung) from 2002 to 2003 (Figure 2). At each site, five 20-m transects were surveyed, and the proportion of coral species with different categories of colony morphologies representing $\mathrm{R}, \mathrm{K}$, and $\mathrm{S}$ strategists were recorded based on the classification system proposed by Edinger and Risk (2000). Each group represents its own unique ecological characteristics: $\mathrm{R}$ comprises weed-like ruderals, $\mathrm{K}$ represents competitors, and $\mathrm{S}$ consists of stress-tolerators. The composition of each coral community was then plotted on an $\mathrm{R}-\mathrm{K}-\mathrm{S}$ ternary diagram and its position on conservation classes (CC) could be identified (Figure 3(a)). Among them, $\mathrm{CC} 1$ represents reefs dominated by stress-tolerators (mainly massive and submassive corals), $\mathrm{CC} 2$ represents those dominated by competitors (mainly foliose and branching non-Acropora corals), CC3 represents those dominated by ruderals (mainly branching and tabular Acropora), and CC4 represents the reefs with mixed coral morphologies or functional groups. It is suggested that reef sites with the highest conservation value $(\mathrm{CC} 4)$ represent the optimum site for conservation, those with moderate conservation values (CC2 and $\mathrm{CC} 3)$ are also suitable candidates for conservation, while those with a lower conservation value (CC1) are damaged or stressed communities and not suitable for conservation (Edinger and Risk, 2000). After the 12 sites were plotted on the diagram, priority candidate sites for conservation could be identified.

\section{Live coral cover, zonation and biota of CIB}

In addition to the snapshot survey of coral communities, four reef sites in the Penghu Islands, including CIB, Chinwan Outer Bay, Chitou and Shertosan were surveyed annually from 1999 to 2004 by a modified Reef Check protocol (Hodgson, 1999) for documenting long-term variations in coral cover (Figure 2). At each site, one $50-\mathrm{m}$ transect was laid at 3 and $6 \mathrm{~m}$ depths respectively, and the categories of benthos or substrate were recorded at $20-\mathrm{cm}$ intervals. The abundance of fish and invertebrate indicators within a $5 \mathrm{~m}$ wide belt on the transect was also recorded. After CIB was chosen as a candidate site, an extensive survey of the fauna and flora was conducted by scuba diving in 2003. Habitat types as well as species and relative abundance of corals were recorded.

\section{Status of resource utilization}

All fishing and harvesting activities occurring at CIB were recorded from October to December 2002. Various information on fishing activities was recorded including fishing location, operation time, fishing method and harvest rate, together with the species composition of the total catch, species names and other biological parameters (fork length, body weight, sex, gonad weight) of the target species.

\section{Threats to CIB}

During the annual Reef Check survey, the occurrences of anchor damage along the 50-m transect were recorded based on evidence of obviously smashed and broken pieces of coral colonies. In 2003, the corallivorous gastropods, Drupella snails (D. cornus, D. concatenate, D. eburnea, D. fragum, and D. minuta) were found in CIB. In order to determine the distribution and density of Drupella snails, a transect was laid seaward, perpendicular to the shore, until the edge of reef. Three $1-\mathrm{m}^{2}$ quadrats were surveyed at $10-\mathrm{m}$ intervals. All snails in the quadrat were collected and counted, and their location and host coral species were recorded. 

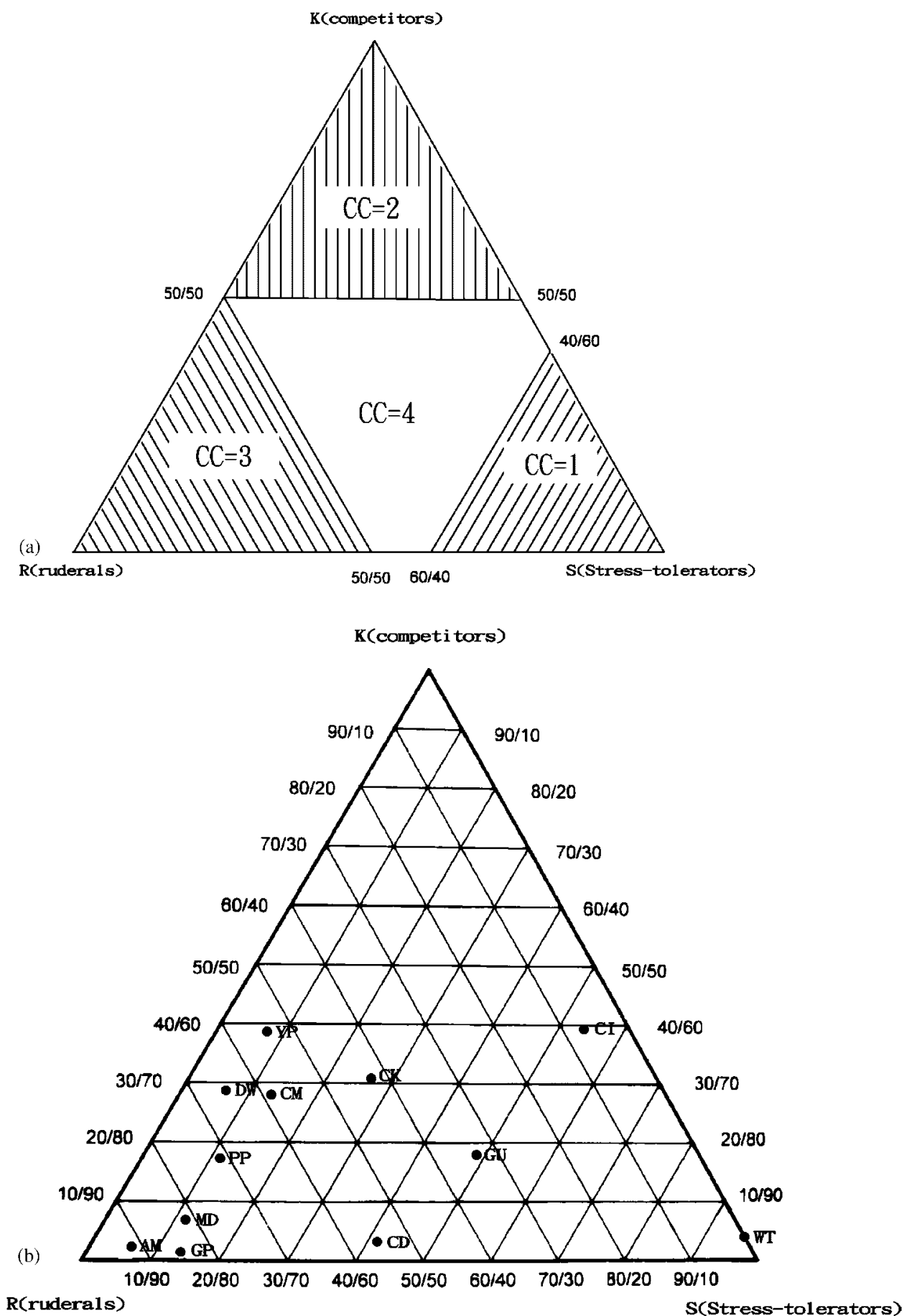

Figure 3. (a) Idealized R-K-S ternary diagram showing the conservation classes (redrawn from Edinger and Risk (2000)). (b) R-K-S ternary diagram of the 12 reef sites in the Penghu Islands (AI: Aimen; CD: Chudra; CIB: Chinwan Inner Bay; CK: Chungkwang; CM:

Chimei; DW: Dawen; GP: Gipei; GU: Gupo; MD: Mudo; PP: Ponpon; WT: Watung; YP: Yupin). 


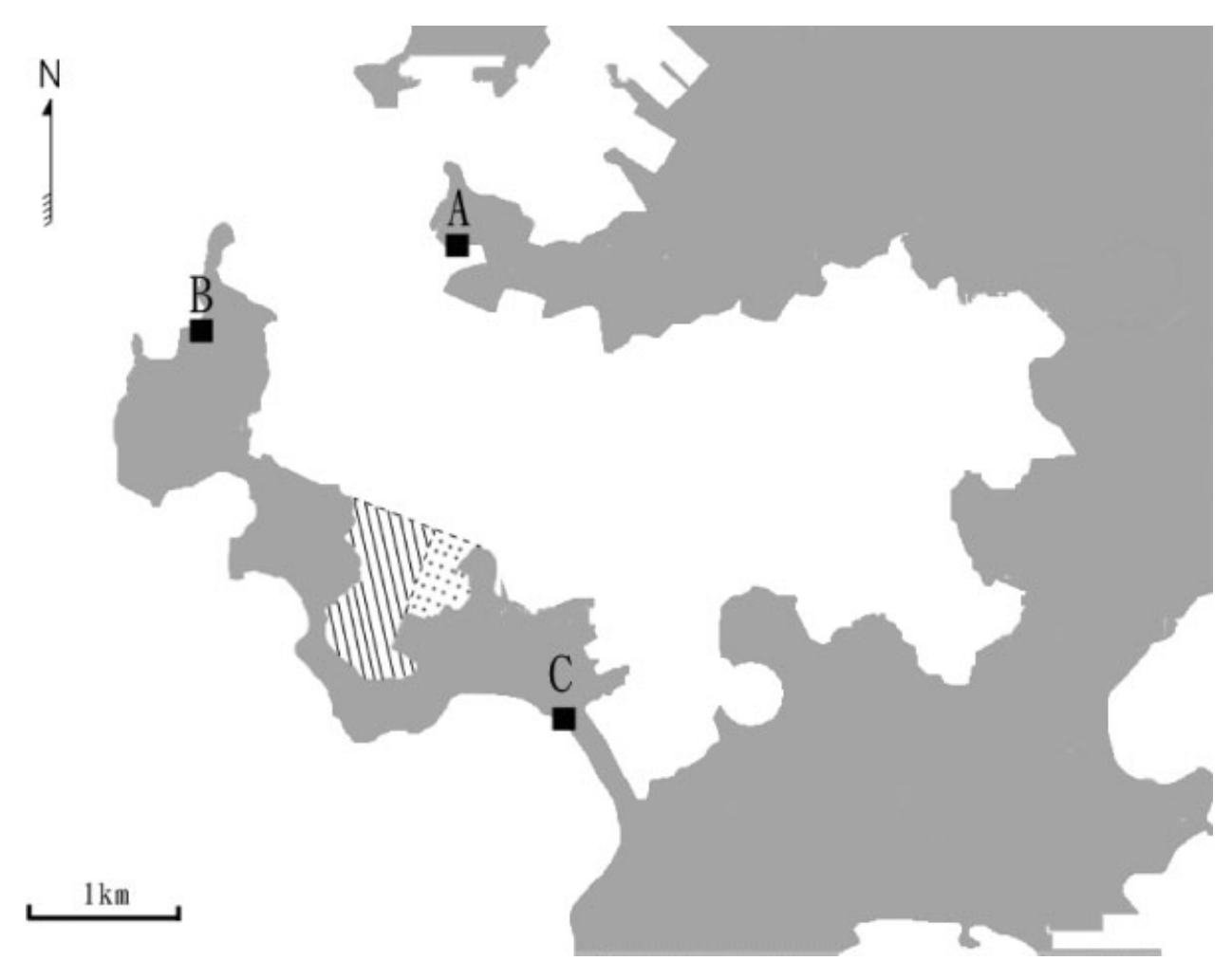

Figure 4. Map of CIB and neighbouring villages (B: Fenguei; C: Shili), the navy base (A), and the boundary of proposed MPA at CIB.

\section{Socio-economic factors}

CIB is located between the Shili and Fenguei Villages on the main island of Penghu (Figure 4). Although historically used by local residents for recreation and amateur fishing, this bay has not been claimed and is not owned by either of the two villages. In order to fully understand the attitude of the local communities toward the MPA, a comprehensive survey was conducted. All families in the neighbouring villages (386 at Shili and 430 at Fenguei) were visited in 2002, and a questionnaire concerning their economic information, financial dependence on the CIB, their knowledge about the marine environment, and their attitudes toward the establishment of an MPA was completed (Tables 1-3).

\section{RESULTS}

\section{Conservation values}

The results of snapshot surveys at 12 sites in the Penghu Islands showed that coral communities at eight sites were classified as CC3 indicating the dominance of branching and tabular Acropora in the coral communities, whereas the coral community at Watung was classified as a stress-tolerating community (CC1) (Figure 3(b)). Coral communities at CIB, Gupo and Chungkwang were classified as CC4, indicating that the coral communities were composed of species with diverse morphologies or functional groups. These sites represent the coral communities with higher conservation values and are appropriate candidates for conservation effort (Edinger and Risk, 2000). 
Table 1. Questionnaire and statistical results of utilization of marine resources in CIB

\begin{tabular}{|c|c|c|}
\hline Question & Shili & Fenguei \\
\hline $\begin{array}{l}\text { Have you ever been to CIB? Yes. } \\
\text { How often do vou go to CIB? }\end{array}$ & $59 \%$ & $46 \%$ \\
\hline (i) Several times a day & $1.0 \%$ & $0 \%$ \\
\hline (ii) Every day & $6.3 \%$ & $0.5 \%$ \\
\hline (iii) Once every several days & $33.7 \%$ & $3.8 \%$ \\
\hline (iv) Once a week & $11.1 \%$ & $2.9 \%$ \\
\hline (v) Once a month & $5.8 \%$ & $7.2 \%$ \\
\hline (vi) Occasionally & $37.5 \%$ & $71.6 \%$ \\
\hline \multicolumn{3}{|l|}{ What is your purpose at CIB? } \\
\hline (i) Fishing & $89 \%$ & $88 \%$ \\
\hline (ii) Recreation & $11 \%$ & $10 \%$ \\
\hline (iii) Research & $0 \%$ & $2 \%$ \\
\hline (iv) Outdoor education & $0 \%$ & $0 \%$ \\
\hline (v) Others & $0 \%$ & $1 \%$ \\
\hline \multicolumn{3}{|c|}{ What kind of fishing method do you use in CIB? } \\
\hline (i) Gill net & $14 \%$ & $8 \%$ \\
\hline (ii) Angling & $14 \%$ & $30 \%$ \\
\hline (iii) Spear fishing & $2 \%$ & $3 \%$ \\
\hline (iv) Raking clams & $28 \%$ & $18 \%$ \\
\hline (v) Picking snails & $36 \%$ & $22 \%$ \\
\hline (vi) Hook snails & $1 \%$ & $12 \%$ \\
\hline (vii) Scraping seaweed & $4 \%$ & $5 \%$ \\
\hline (viii) Others & $1 \%$ & $1 \%$ \\
\hline \multicolumn{3}{|l|}{ How do you use the harvest? } \\
\hline (i) Self-consumption & $90 \%$ & $72 \%$ \\
\hline (ii) For sale & $10 \%$ & $28 \%$ \\
\hline \multicolumn{3}{|c|}{ How much benefit (in NT\$) do you gain from the harvest per year? } \\
\hline (i) $<5000$ & $61 \%$ & $100 \%$ \\
\hline (ii) $5000-10000$ & $26 \%$ & $0 \%$ \\
\hline (iii) $10000-15000$ & $4 \%$ & $0 \%$ \\
\hline (iv) $15000-20000$ & $0 \%$ & $0 \%$ \\
\hline (v) $20000-25000$ & $4 \%$ & $0 \%$ \\
\hline (vi) $25000-30000$ & $4 \%$ & $0 \%$ \\
\hline (vii) $>30000$ & $0 \%$ & $0 \%$ \\
\hline
\end{tabular}

\section{Live coral cover, zonation and biota of CIB}

Among the four sites monitored from 1999 to 2004, the live coral cover at CIB remained the highest and relatively stable (Figure 5). Coral cover at the other three sites was lower and more variable, owing to the influences of typhoons and sedimentation (Dai et al., 2002). Forty-one species of scleractinian corals belonging to three families and 10 genera were recorded at CIB, representing $c a 33 \%$ of the total number of coral species found in the Penghu Islands. Galaxea astreata, Montipora cactus and Acropora muricata were among the most abundant species between 3 and $6 \mathrm{~m}$ depth, while Euphyllia paraancora forms a monospecific carpet between 6 and $8 \mathrm{~m}$ depth (Figure 6).

Although the area of CIB is small (less than 80 ha), it contains various habitats and associated biological communities (Figure 6). The intertidal rocky substrates are populated with turbo and littorinid snails, and oysters, whereas the sandy bottom dominanted by clams. At $1.5-3.0 \mathrm{~m}$ depth, the substrate is covered with seagrass meadows of Halophila ovalis (R.Br.) Hook. f., which are important nursery grounds for juvenile fishes and invertebrate larvae. The sea bottom at $3-8 \mathrm{~m}$ depth is occupied by well-developed coral 
Table 2. Questionnaire and statistical results concerning the present status of CIB

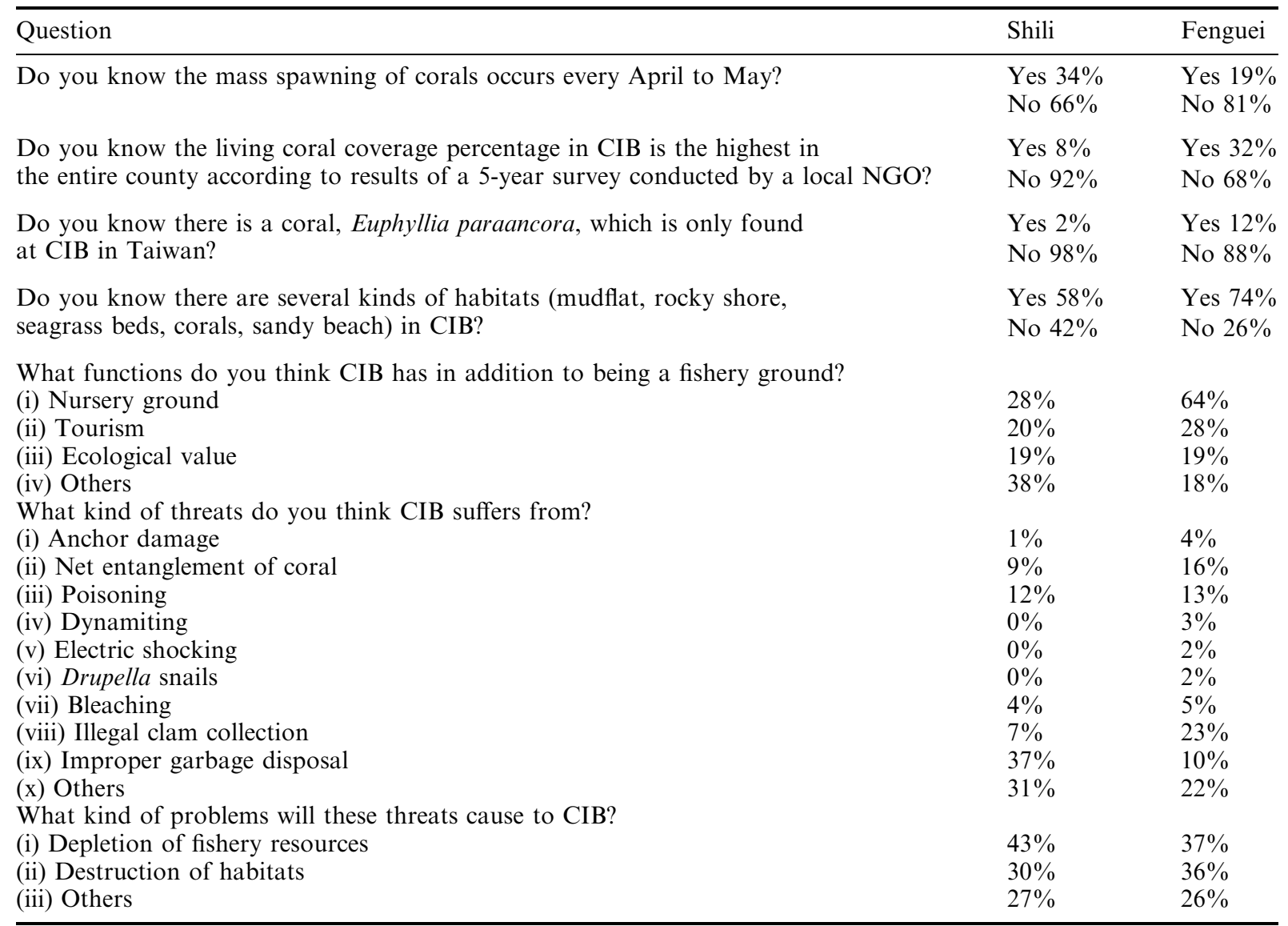

Table 3. Questionnaire and statistical results concerning resource and habitat conservation of CIB

\begin{tabular}{lll}
\hline Question & Shili & Fenguei \\
\hline Do you know what a Marine Protected Area (MPA) is? & Yes 41\% & Yes $86 \%$ \\
& No 59\% & No $14 \%$ \\
Do you know that not all MPAs are access-denied? & Yes 16\% & Yes $50 \%$ \\
& No 84\% & No 50\% \\
For the purpose of conservation, are you willing to restrict your own & Yes 69\% & Yes 99\% \\
fishing behaviours within a reasonable range, such as restriction on places, & No 31\% & No 1\%
\end{tabular}

period, methods, body lengths of organisms, etc.?

Will you stop catching organisms during their reproduction seasons?

Yes $70 \%$

No $30 \%$

Yes $73 \%$

Yes $97 \%$

If the problems in CIB could be solved by establishing an MPA and your

No $27 \%$

No $3 \%$

income was not affected, would you support the establishment of an MPA?

Yes $73 \%$

Yes $98 \%$

The Penghu County government intends to promote MPA establishment at

No $27 \%$

Yes $98 \%$ CIB. If this project will increase the fishery production, will you support it? 

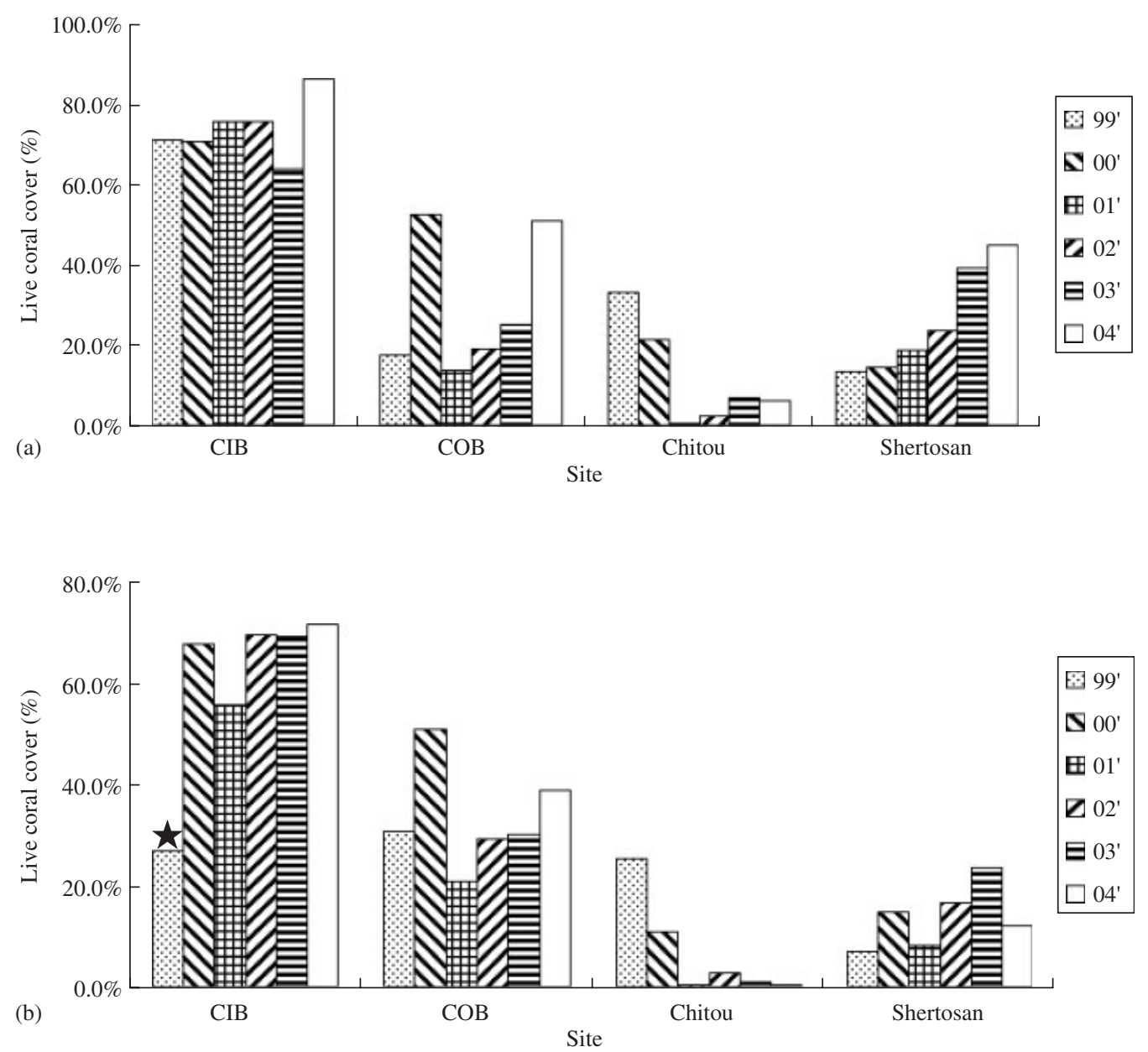

Figure 5. Annual variations of live coral cover at (a) $3 \mathrm{~m}$ depth, and (b) $6 \mathrm{~m}$ depth at four sites in the Penghu Islands from 1999 to 2004. CIB: Chinwan Inner Bay, COB: Chinwan Outer Bay. The star indicates an underestimated value in $6 \mathrm{~m}$ in 1999 due to a misunderstanding of the survey procedure.

communities, where reef fishes such as butterflyfishes, groupers and emperors are common. Below $8 \mathrm{~m}$, there are sand- and mudflats which extend from the edge of the reefs to a deeper slope. This habitat is rich in flounders, goatfishes and common silver biddy fishes.

\section{Status of resource utilization in $\mathbf{C I B}$}

Most of the fishing operations carried out at CIB were for recreational purposes. This type of fishing is characterized by low investment, low harvest rates, high dependence on weather conditions, and selfconsumption. In October-December 2002, 110 events of boat fishing, 49 of floating raft fishing, 26 of shore fishing, and 36 of intertidal collecting were recorded in 25 days. The other days were too windy or too cold, or the tides were unsuitable for fishery operations.

The 36 intertidal collecting events recorded all occurred during the semidiurnal low tides, in the daytime. The area near the east side of the bay was visited most frequently (Figure 7), and the target organisms were snails and clams. The 61 cases of boat fishing were also concentrated on the east side of CIB (Figure 7). 


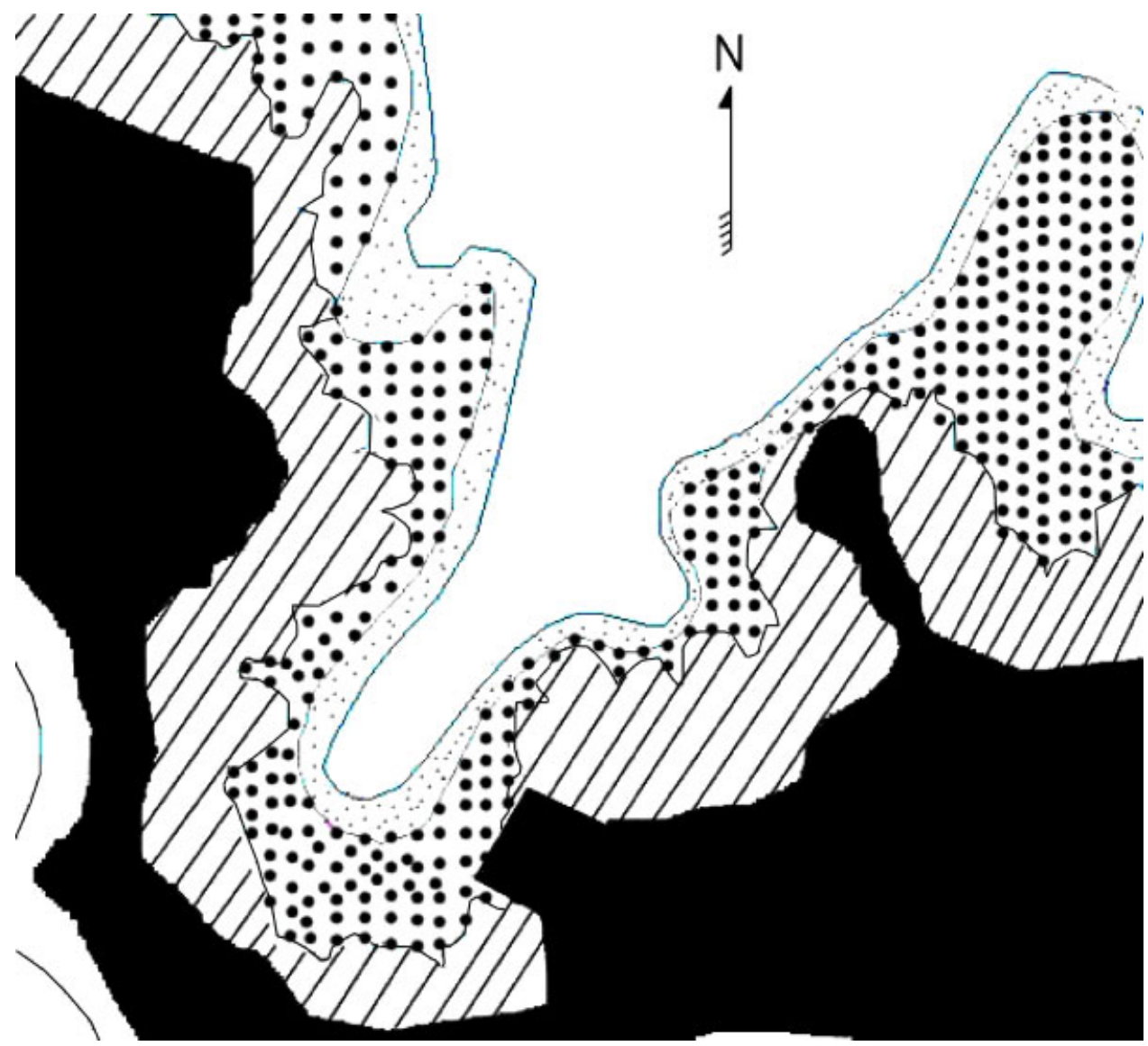

Figure 6. Zonation of habitats and benthic communities at CIB. 'Black area': land mass; 'hatching': intertidal rocky and sandy substrates; 'solid dots': seagrass meadows at 1.5-3.0 m depth; 'stippling': coral communities at 3-8 m depth; 'blank area': mud flat at $>8 \mathrm{~m}$ depth. This figure is available in colour online at www.interscience.wiley.com/journal/aqc

Operating times were not closely related to the tides, and the target organisms were high-valued fishes and crustaceans. Shore fishing was mostly carried out at the abandoned dock to the south of CIB (Figure 7). Floating raft fishing occurred on the west and south sides of CIB where there were sandy and reef bottoms (Figure 7).

In October-November 2002, only two fishing boats constantly operated in CIB. The daily catches of boat fishing and floating raft fishing were $6.52 \pm 2.69 \mathrm{~kg}$ (mean $\pm \mathrm{SD}$ ) and $3.48 \pm 1.29 \mathrm{~kg}$, respectively. Overall, around $20.4 \mathrm{~kg}$ of fish and shellfish were removed daily from CIB; species composition of the catch was highly diverse with 41 fish species in 24 families and 34 genera recorded.

\section{Threats to CIB}

\section{Anchor damage}

No obvious anchor damage events were observed before 2002. From 2002 to 2004, the occurrences of anchor damage increased rapidly indicating that anchoring was a rising threat to coral reefs at CIB (Figure 8). The incidence of anchor damage in CIB was probably underestimated since only one $50-\mathrm{m}$ 


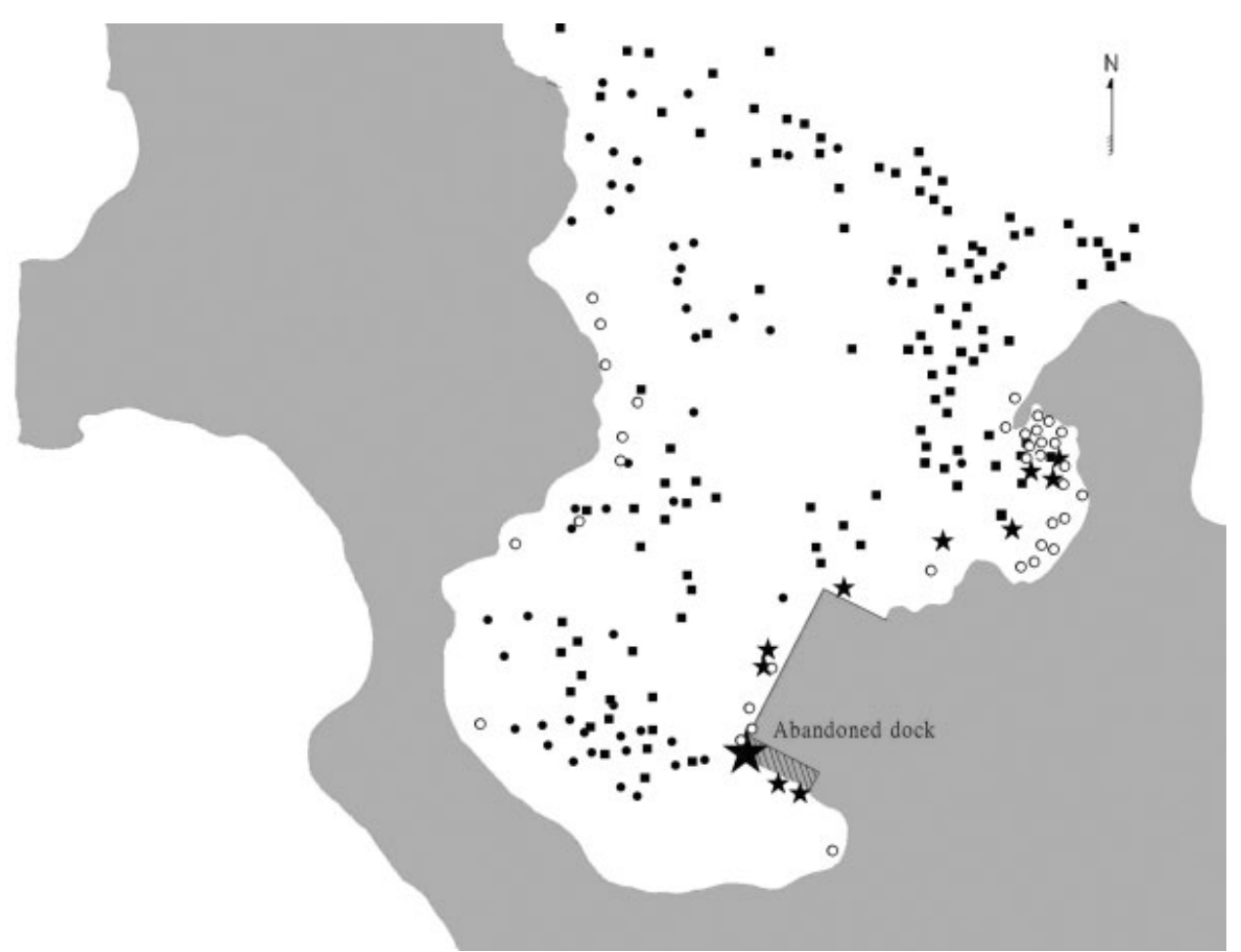

Figure 7. Distribution of all fishing events at CIB from October to December 2002. 'open circle' indicates intertidal collecting; 'solid square' indicates boat fishing; 'solid circle' indicates floating raft fishing; and 'open square' indicates shore fishing. The large star indicates a hotspot with 16 shore fishing events recorded; 'hatching' indicates the abandoned dock.

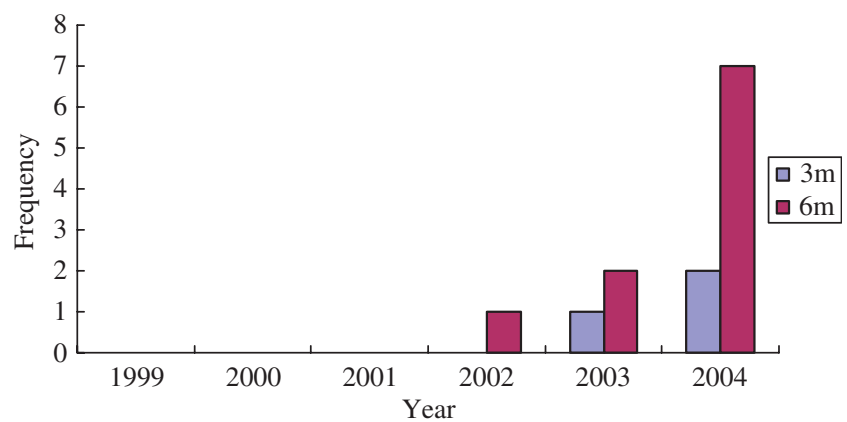

Figure 8. The frequency of anchor damage in the monitoring sites of CIB based on Reef Check data in 1999-2004. This figure is available in colour online at www.interscience.wiley.com/journal/aqc

transect was surveyed at the monitoring site. Judging from the intensive recreational boat fishing and floating raft fishing in CIB, anchor damage could be a significant threat to the coral community.

Drupella snails

Five native species of Drupella (D. cornus, D. concatenate, D. eburnea, D. fragum and D. minuta) were collected at CIB. They co-occurred on the surface of live coral colonies. Among the 27 predated coral 
Table 4. Percentages of families at Shili and Fenguei that belong to five categories of annual disposable income in New Taiwan dollars in 2002

\begin{tabular}{lllllll}
\hline & \multicolumn{5}{c}{ Category } \\
\cline { 2 - 7 } Village & $<192000$ & $192001-384000$ & $384001-576000$ & $576001-840000$ & $840001-1200000$ & $>1200001$ \\
\hline Shili & $34.1 \%$ & $46.6 \%$ & $13.6 \%$ & $5.0 \%$ & $0.3 \%$ & $0.3 \%$ \\
Fenguei & $25.0 \%$ & $28.0 \%$ & $19.0 \%$ & $16.0 \%$ & $3.0 \%$ & $3.0 \%$ \\
\hline
\end{tabular}

In 2002, the average exchange rate was US\$1.00 $=$ NT $\$ 34.62$.

colonies observed, 13 were G. astreata (48\%) and 10 were M. cactus $(37 \%)$. These coral species are the preferred hosts for the snails; other corals that were predated by snails were Acropora muricata, Echinophyllia orpheensis and Lithophllon undulatum. The average density of Drupella snails was $5.5 \mathrm{ind}^{-2}$.

\section{Community awareness and attitudes towards the MPA}

In total, 386 completed questionnaires from Shili and 351 from Fenguei were obtained after the entire populations of the villages were visited. The population from Fenguei ( $\mathrm{pFG}$ ) depended less on CIB than did the people at Shili (pSL) (Table 1). The pSL visited CIB more frequently and earned more money from it than did the pFG (Table 1). Both groups mainly utilized CIB for fishing; however, the pSL employed more diverse fishing methods than did the pFG. Most of the fish caught were consumed by the fishers themselves in both villages.

Although about half of the people of both villages visited and used CIB occasionally and directly, fewer than half of them were aware of the results of scientific research conducted there (Table 2). Among the factors causing degradation of the reef at CIB, improper garbage disposal, land construction (in the category 'other'), illegal triple-layered gill nets, illegal clam collection by smashing coral, poisoning, and coral bleaching were better known to the local population.

About $86 \%$ of the pFG were familiar with MPAs and half of them understood that not all MPAs are access-denied (Table 3). Almost all $(>97 \%)$ of the pFG showed a strong intention to support the establishment of the MPA and indicated that they would restrain their fishing activities during reproduction seasons. On the other hand, $41 \%$ of the pSL were familiar with MPAs and only $16 \%$ understood that not all MPAs are access-denied. When interviewed with the same question, about $31 \%$ of the pSL objected to having to halt fishing activities during reproduction seasons.

The disposable income of each family in the two villages was largely classified into the lowest two levels compared to all families in Taiwan (former 40\% lower income) (Table 4). The annual disposable income of $80.7 \%$ of the families at Shili and $63 \%$ at Fenguei was less than NT\$384 000 (approximately US\$11 100). The differences in the economic structures between the two villages may have been the cause of inconsistency in their dependence and their attitude toward the same issues.

\section{DISCUSSION}

\section{CIB as the priority site of the establishment of an MPA}

The high conservation value, high coral cover and species diversity in CIB suggests that it is a site with good potential for the conservation of biodiversity of coral reefs in the Penghu Islands. In addition, various types of habitats including the intertidal basalt rocky shore, a subtidal coral community, seagrass beds, and sandy/muddy substrates exist within the bay (Hsieh et al., 2001). A diverse biota can also be found in 


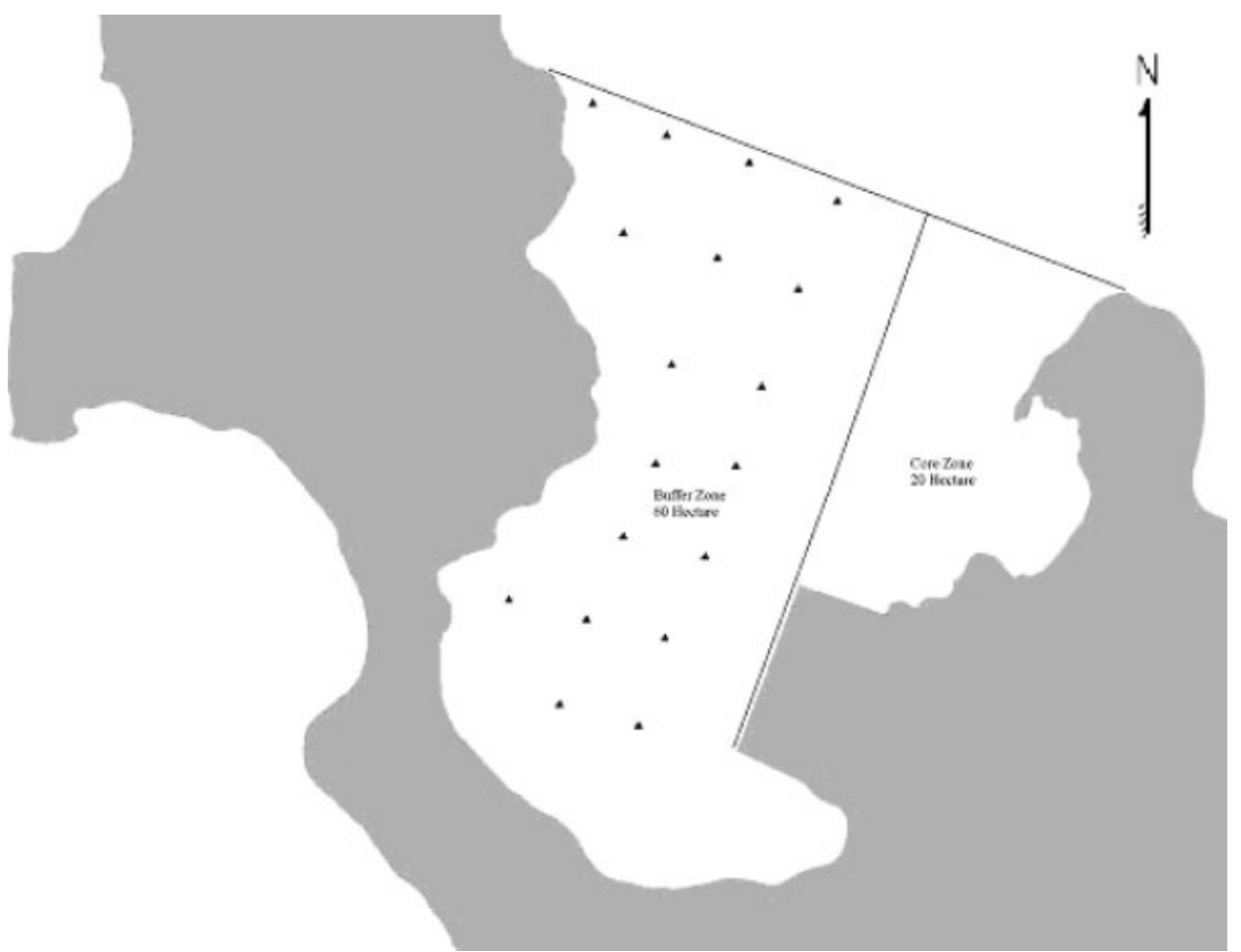

Figure 9. Recommended zoning plan for the MPA at CIB. Solid triangles are proposed sites for anchor buoys.

various habitats of the bay. Thus the establishment of CIB MPA is likely to be beneficial both for the conservation of biodiversity and to the conservation of commercial fish species in the Penghu Islands.

Coral communities at CIB are well-developed compared to other places in Penghu Islands possibly because it is protected from waves and illegal fishing practices by the surveillance of a nearby navy base (Hsieh et al., 2002). However, this bay is nevertheless facing anthropogenic and ecological stresses including anchor damage and the proliferation of corallivorous gastropods. Anchor damage to coral reefs and communities has long been reported as one of the major factors in reef destruction (Davis, 1977; Dinsdale and Harriott, 2004). Using anchor buoys instead of regular anchors has been recommended to avoid causing mechanical destruction to coral colonies. After evaluating the damage, practical anchor buoys were designed, and areas for their deployment were recommended according to distribution patterns of coral and fishing activities (Figure 9).

\section{Blueprint for the MPA at CIB}

Studies have shown that 'no-take areas' of MPAs can effectively increase population densities of animals including fishes and improve the catch per unit effort (Polunin and Roberts, 1993; McClanahan and Kaunda-Arara, 1996; Kamukuru et al., 2004). Even small reserves $\left(0.4 \mathrm{~km}^{2}\right)$ can successfully enhance local fish stocks, especially those territorial and non-migratory species such as snappers and parrotfishes (Roberts and Hawkins, 1997). Fishers and local inhabitants can benefit from the spillover and sustained propagation from the no-take area. Based on the results of both ecological and socio-economic studies, a blueprint for the designation of CIB as the first MPA in Taiwan is presented. 
An area of approximately 20 ha on the east side of the bay that includes various habitat types and supports high species diversity is proposed as the 'core zone' (Figure 9) or 'no-take area'. All activities here would be strictly prohibited except scientific research with permission from the administrating authority (the Penghu Agriculture and Fishery Bureau). The other 60 ha of subtidal area on the west side is recommended as a 'buffer zone' to reduce the impact to traditional resources utilization of the neighbouring villages. Traditional fishery operations would be allowed here under adequate regulations such as bans on use of gill nets, bottom trawling, light traps, poisoning, dynamiting and electric shock fishing. To prevent anchor damage to corals, 18 anchor buoys will be deployed evenly within the buffer zone for boat and floating raft fishing operations. Regulations on body length, fishing period, fishing methods and total allowable catch for target species will be implemented in the future with the aim of conserving the fishery resources.

Although the recommended MPA at CIB is small, it is an important first step and has the potential to be effective not only in enhancing biodiversity conservation but also in illustrating the benefits to activities such as fishing. The creation of MPAs within fishing grounds can be beneficial to the fishery by providing a refuge for part of the stock and thus, possibly increasing overall production (Roberts et al., 2001). The success of this MPA at CIB may provide a model for a network of sites that could deliver better conservation of marine resources and biodiversity in Taiwan.

The future of the MPA at CIB, whether expressed in human or environmental terms, is dependent on effective and responsible management. Such management practices, in general, would benefit from increased community involvement. This would require renewed emphasis on feelings of ownership and increased knowledge of the environment by the general public (Evans and Birchenough, 2001). Although most of the people in local villages support the establishment of the MPA at CIB, some controversies still exist among stakeholders. Apparently, more efforts should be made to promote public awareness toward the establishment of an MPA at CIB, not only for people in the two villages but also for people throughout Penghu Islands. Environmental education is recommended to bring about the changes in public perceptions and attitudes. Unless a common understanding and interpretation of the significance of MPA is achieved among multiple stakeholders its management will continue to be filled with tension and threaten community solidarity. There is, therefore, an urgent need for initiatives in environmental education, which operate outside the formal system and address all ages and sections of society.

\section{ACKNOWLEDGEMENTS}

Special thanks go to Ms Li-Hong Huang for compiling and analysing the data. Mr Nen-Jeng Chen (Shili) and Ms Su-Ting Chen (Fenguei) visited every family in those villages. Mr Yi-Lo Shen drew the figures and handled image-processing. Many experienced volunteers unselfishly contributed to this labour-intensive fieldwork. Dr Zohar Pasternak refined the manuscript and provided constructive comments. This study was sponsored by the Penghu Agriculture and Fishery Bureau to the Penghu Zooxanthellae Association. Reef Check was supported by the Fishery Agent, Council of Agriculture, R.O.C.

\section{REFERENCES}

Agardy T, Bridgewater P, Crosby MP, Day J, Dayton PK, Kenchinton R, Laffoley D, McConney P, Murray PA, Parks JE, Peau L. 2003. Dangerous targets: differing perspectives, unresolved issues, and ideological clashes regarding marine protected areas. Aquatic Conservation: Marine and Freshwater Ecosystems 13: 1-15.

Alder J, Zeller D, Pitcher T. 2002. A method for evaluating marine protected area management. Coastal Management 30: $121-131$. 
Ballantine WJ. 1997. 'No-take' marine reserve networks support fisheries. In Developing and Sustaining World Fisheries Resources: The State and Management, Hancock DA, Smith DC, Grant A, Beumer JP (eds), 2nd World Fisheries Congress Proceedings. CSIRO Publishing: Collingwood, Australia; 702-706.

Beck MW, Odaya M. 2001. Ecoregional planning in marine environments: identifying priority sites for conservation in the northern Gulf of Mexico. Aquatic Conservation: Marine and Freshwater Ecosystems 11: 235-242.

Bohnsack JA, Causey B, Crosby MP, Griffis RB, Hixon MA, Hourigan TF, Koltes KH, Maragos JE, Simons A, Tilmant JT. 2000. A rationale for minimum 20-30\% no-take protection. In Proceedings of the 9th International Coral Reef Symposium, vol. 2, Kasim Moosa MK, Soemodihardjo S, Nontji A, Soegiarto A, Romimohtarto K, Sukarno, Suharsono (eds). International Society for Reef Studies, Bali, Indonesia; 615-619.

Chen CA. 1999. Analysis of scleractinian distribution in Taiwan indicating a pattern congruent with sea surface temperatures and current: examples from Acropora and Faviidae corals. Zoological Studies 38: 119-129.

Costanza R, Andrade F, Antunes P, van den Belt M, Boersma D, Boesch DF, Catarino F, Hanna S, Limburg K, Low B et al. 1998. Principles for sustainable governance of the oceans. Science 281: 198-199.

Dai CF. 1997. Assessment of the present health of coral reefs in Taiwan. In Status of Coral Reefs in the Pacific, Grigg RW, Birkeland C (eds). Sea Grant Program, University of Hawaii: Honolulu; 123-131.

Dai CF, Soong K, Chen CA, Hwang JS, Fan TY, Hsieh HY, Chang JS. 2002. The status of coral reefs in Taiwan and the conservation problems. In Proceedings of the 4th Conference on the Protected Areas of East Asia, Tsai HM (ed.). Taiwan Organizing Committee for IUCN/WCPA-EA4: Taipei; 265-276.

Davis GE. 1977. Anchor damage to a coral reef on the coast of Florida. Biological Conservation 11: 29-34.

Dinsdale EA, Harriott VJ. 2004. Assessing anchor damage on coral reefs: a case study in selection of environmental indicators. Environmental Management 33: 126-139.

Edinger EN, Risk MJ. 2000. Reef classification by coral morphology predicts coral reef conservation value. Biological Conservation 92: 1-13.

Evans SM, Birchenough AC. 2001. Community-based management of the environment: lessons from the past and options for the future. Aquatic Conservation: Marine and Freshwater Ecosystems 11: 137-147.

Hodgson G. 1999. A global assessment of human effects on coral reefs. Marine Pollution Bulletin 38: $345-355$.

Hsieh HJ, Wei NV, Lu YL, Jeng MS, Tsai WS, Chen CA. 2001. Unexpectedly high coral coverage in Chinwan Inner Bay, Pescadores: a proposed site for a marine protection area. Coral Reefs 20: 316-317.

Hsieh HJ, Wei NV, Lu YL, Jeng MS, Tsai WS, and Chen CA. 2002. Unexpectedly high coral coverage and genetic uniqueness of Euphyllia coral in Chinwan Inner Bay, Pescadores: a proposal site for a marine protection area. In Proceedings of the 4th Conference on the Protected Areas of East Asia: Benefits beyond Boundaries in East Asia, Tsai HM (ed.). Taiwan Organizing Committee for IUCN/WCPA-EA4; Taipei; 303-310.

Jan S, Wang J, Chern CS, Chao SY. 2002. Seasonal variation of the circulation in the Taiwan Strait. Journal of Marine Systems 35: 249-268.

Jeng WL, Dai CF, Fan KL. 1999. Taiwan Strait. In Seas at the Millennium: An Environmental Evaluation, Vol. II, Sheppard CRC (ed.). Elsevier: Amsterdam; 499-512.

Juang WS, Chen JC. 1992. Geochronology and geomorphology of Penghu basalts, Taiwan Strait and their tectonic significance. Journal of Southeast Asian Earth Science 7: 185-193.

Kaiser MJ. 2004. Marine protected areas: the importance of being earnest. Aquatic Conservation: Marine and Freshwater Ecosystems 14: 635-638.

Kamukuru AT, Mgaya YD, Öhman MC. 2004. Evaluating a marine protected area in a developing country: Mafia Island Marine Park, Tanzania. Ocean and Coastal Management 47: 321-337.

Kimura T, Dai CF, Pae S, Huang H, Ang PO, Jong GJ, Choyce C. 2004. Status of coral reefs in east and north Asia: China, Hong Kong, Taiwan, Korea and Japan. In Status of Coral Reefs of the World: 2004, Wilkinson C (ed.). Australian Institute of Marine Science: Townsville, Australia; 277-301.

Lauck T, Clark CW, Mangel M, Munro GR. 1998. Implementing the precautionary principle in fisheries management through marine reserves. Ecological Applications 8: S72-S78.

McClanahan TR, Kaunda-Arara B. 1996. Fishery recovery in a coral reef marine park and its effects on the adjacent fishery. Conservation Biology 10: 1187-1199.

McClanahan TR, Mangi S. 2000. Spillover of exploitable fishes from a marine park and its effects on the adjacent fishery. Ecological Applications 10: 1792-1805.

Murray SN, Ambrose RF, Bohnsack JA, Botsford W, Carr MH, Davis GE, Dayton PK, Gotshall D, Gunderson DR, Hixon MA et al. 1999. No-take reserve networks: sustainable fishery populations and marine ecosystems. Fisheries management perspectives. Fisheries 24: 11-25.

NRC (National Research Center). 2001. Marine Protected Areas: Tools for Sustaining Ocean Ecosystems. National Academy Press: Washington, DC. 
Polunin NVC, Roberts CM. 1993. Greater biomass and value of target coral reef fishes in two small Caribbean marine reserves. Marine Ecology Progress Series 100: 167-176.

Roberts CM, Hawkins JP. 1997. How small can a marine reserve be and still be effective? Coral Reefs 16: 150.

Roberts CM, Bohnsack JA, Gell F, Hawkins JP, Goodridge R. 2001. Effects of marine reserves on adjacent fisheries. Science 294: 1920-1923.

Roff JC, Evans SMJ. 2002. Framework for marine conservation - non-hierarchical approaches and distinctive habitats. Aquatic Conservation: Marine and Freshwater Ecosystems 12: 635-648.

Rowley RJ. 1994. Marine reserves in fisheries management. Aquatic Conservation: Marine and Freshwater Ecosystems 4: $233-254$.

Stevens T. 2002. Rigor and representativeness in marine protected area design. Coastal Management 30: 237-248.

Sumaila UR. 1998. Protected marine reserves as fisheries management tolls: a bioeconomic analysis. Fisheries Research 37: 287-296.

USCRTF. 2000. The National Action Plan to Conserve Coral Reefs. US Coral Reef Task Force. Washington, DC. http://coral reef.gov 